\title{
FASCICLE DENSITY AND NEEDLE GROWTH RESPONSES OF RED PINE TO WATER SUPPLY OVER TWO SEASONS ${ }^{1}$

\author{
Peter W. Garrett \\ U.S. Department of Agriculture, Forest Service, \\ Northeastern Forest Experiment Station, Durham, New Hampshire 03824 \\ AND \\ ROBERT ZAHNER \\ School of Natural Resources, The University of Michigan, \\ Ann Arbor, Michigan 48104
}

\begin{abstract}
The ontogeny of terminal growth in red pine (Pinus resinosa Ait.) suggests that the growing season in Michigan be divided into three 2-month periods: April-May, June-July, and August-September. It is during the middle period that mitotic activity at the shoot apex initiates dwarf shoot primordia in the bud for the subsequent season's foliage; thus, preconditioning one year has a strong effect on next year's growth.

Water was applied to or withheld from the soil under 23-year-old trees in various combinations of the 2-month periods over two growing seasons. All effects of drought were greatest on the terminal shoot of the main stem, diminishing on terminals of branches with distance from the apex, and disappearing at the base of the crown.

Shoot extension was governed equally by conditions of the middle period of the previous year and of the early period of the current year. Each year fascicle density was regulated only by water conditions of the early period of the current year, regardless of preconditioning. Spacing of needles on shoots depended on elongation of the stem internodes between dwarf shoots, and was independent of the number of fascicles.

Number of fascicles per shoot was governed only by conditions of June-July of the previous year, with drought during this period reducing the number by $30 \%$. Length of needles was related to two factors: the number of fascicles produced per shoot and the water treatment of the period during which needles elongated. Thus when the water supply of the middle of the previous year was deficient, fewer but longer needles were produced currently; when water during the middle of the current year was deficient, needles were reduced in length by about $30 \%$.

It is concluded that the interaction of two seasons' water supply are usually compensative, rarely additive. The average net effect on foliage production is a long-term, year-to-year stability in photosynthetic potential for red pine.
\end{abstract}

\section{INTRODUCTION}

It is well documented that environmental conditions of both the previous and current seasons have large effects on extension growth in red pine (Pinus resinosa Ait.) (Zahner 1968). This species exhibits a single growth flush from tissue preformed in the overwintering bud. Duff and Nolan (1958), Kozlowski (1963), and Marion et al. (1968) have emphasized the importance of the previous season's environment, during the period of bud formation, on production of dwarf shoot primordia for current year needles. Lotan and Zahner (1963) and Clements (1970) have shown that the number of needle fascicles are in fact influenced by the previous season's environment and not significantly by the current. They also found that needle length is strongly influenced by conditions of the current season, when needles are elongating.

This paper considers the interaction of the water supply of 2 succeeding years on the development of foliage on terminal shoots in red pine trees. Of

\footnotetext{
${ }^{1}$ Received March 4, 1971; accepted October 27, 1971.
}

particular interest is the preconditioning effect of water withheld or supplied during the early, middle, or late portions of one season on growth the subsequent season. During the middle of the first season mitotic activity at the shoot apex initiates cataphyll primordia and their accompanying mounds of meristematic tissue that develop into dwarf shoot primordia. The following spring leaf primordia are initiated from these dwarf shoots, producing the second season's foliage (Sacher 1954, Duff and Nolan 1958). In red pine the critical middle period of the first season begins when current shoots are about half extended, approximately June 1 in northern Lower Michigan. The effect of environmental conditions before, during, and after this period of tissue development in the bud is not well established.

Elongation of terminal shoots in red pine is usually complete within 8 weeks after buds enlarge in the spring, regardless of current weather conditions. The rate of extension growth is affected by both the amount of preformed tissue and the current weather conditions, since Zahner and Stage (1966) found water deficits of both seasons equally important in 
TABLE 1. List of water supply treatments by period and year. Each horizontal line is a complete treatment

\begin{tabular}{|c|c|c|c|c|}
\hline \multirow[b]{2}{*}{ Treatment $^{\mathbf{a}}$} & \multicolumn{3}{|c|}{1962} & \multirow[b]{2}{*}{$\begin{array}{c}1963 \\
\text { Apr.-Sept. }\end{array}$} \\
\hline & $\begin{array}{l}\text { Apr.- } \\
\text { May }\end{array}$ & $\begin{array}{c}\text { June- } \\
\text { July }\end{array}$ & $\begin{array}{l}\text { Aug.- } \\
\text { Sept. }\end{array}$ & \\
\hline 1. W W W - W & Wet & Wet & Wet & Wet \\
\hline 2. $W W W-D$ & Wet & Wet & Wet & Dry \\
\hline 3. WW D - W & Wet & Wet & Dry & Wet \\
\hline 4. W W D - D & Wet & Wet & Dry & Dry \\
\hline 5. W D W-W & Wet & Dry & Wet & Wet \\
\hline 6. W D W - D & Wet & Dry & Wet & Dry \\
\hline 7. DDD-W & Dry & Dry & Dry & Wet \\
\hline 8. D D D - D & Dry & Dry & Dry & Dry \\
\hline 9. $\mathrm{DWD}-\mathrm{W}$ & Dry & Wet & Dry & Wet \\
\hline 10. D W D - D & Dry & Wet & Dry & Dry \\
\hline 11. C C C-C & Check & Check & Check & Check \\
\hline
\end{tabular}

a The first 3 letters designate the sequence of water supplied during the 3 periods in 1962; the last letter designates that of the entire 1963 season.

contributing to the annual variation in height growth of this species. Therefore, it was thought that needle fascicle density on shoots may depend on some interaction between the environments of two seasons.

\section{Methods}

The study was conducted in a 23 -year-old red pine plantation $(2 \times 2 \mathrm{~m}$ spacing $)$ growing on a level outwash plain of glacial meltwater origin in northern Lower Michigan. The soil is Grayling sand, a welldrained entisol with poor fertility and total available water capacity of only $6 \mathrm{~cm}$ in the surface meter of soil. Thirty-three dominant trees, averaging 7-8 m in total height and $12-16 \mathrm{~cm}$ in diameter at breast height, were selected for uniformity of size and past growth. Crowns were about $50 \%$ of total height, and annual height growth had averaged about $40 \mathrm{~cm}$ for several years before the study began. Selected trees were spaced about $10 \mathrm{~m}$ apart.

A trench $1.2 \mathrm{~m}$ deep was dug around each of the 33 study trees, isolating a 10 -square-m area of soil with the selected tree in the center. Several adjacent trees of intermediate crown class were included within the trenched area around each study tree. No thinning was done.

Three study trees were assigned randomly to each of 11 treatments (Table 1). The ontogeny of terminal growth in red pine suggested that the 1962 growing season be divided into three 2-month periods: early, April 1-May 31; middle, June 1-July 31; and late, August 1-September 30. Water was applied to or withheld from the trenched areas around each tree for five combinations of periods during the 1962 season. Each of the five combinations of the 1962 season was paired with two treatments during the 1963 season, resulting in a total of ten water supply treatments. There were three check trees.
During each period trees in those treatments designated as "wet" were provided with a minimum of $5 \mathrm{~cm}$ of water per week, including both irrigation and natural rainfall. The supplemental water was obtained from a nearby source of natural ground water in the sand parent material and was consequently extremely low in nutrient content. Water including rainfall was withheld entirely from the soil of those trees in treatments designated as "dry" for any period. Rain was excluded by low sheds constructed over the trenched area, and all runoff and stemflow water was disposed of outside the trenched area. The sheds were constructed and removed at the beginning and end of each period, as required by the treatments. All trees received natural soil water recharge over the winter of 1962-63.

We measured shoot and needle elongation weekly during both 1962 and 1963 seasons on seven terminal shoots of each study tree: the main stem leader, and two leaders from each of the third, fifth, and seventh branch whorls moving basipetally from the top. On each of these long shoots needles were measured at several positions. Terminal buds on the seven measured shoots were measured in the fall of 1961, 1962, and 1963. In the fall of 1963 we collected all needle fascicles from the 1961, 1962, and 1963 portions of the main stem and the six branch leaders previously measured. The total number of fascicles, needle size, and total dry weight were obtained by year and by position.

The effects of treatment on shoot and needle production were tested by analysis of variance and Duncan's multiple range test, and by standard $t$-tests where appropriate. Unless otherwise stated, differences due to treatments were significant at the $1 \%$ level.

\section{RESUlts}

Differences in foliage development due to treatments, that is, effects on extension growth of shoots, on needle elongation, on fascicle numbers, and on fascicle density, were all greatest on main stem leaders and relatively less on terminals of branches located farther down the crown. Foliage development at the lowest crown position measured, that of terminal shoots on the seventh branch whorl from the top, was not affected by any treatment. This lowest crown position is not included in results presented below. At all other crown positions shoot growth was significantly affected by treatments, even though the magnitude of differences was often quite small on the fifth branch whorl. All effects of drought were greatest in the upper crown, diminishing with distance from apex and disappearing at the base of the crown. 
TABLE 2. Needle and shoot production data for terminal shoots developed during 1962. Values are averages for all trees in all treatments providing or withholding water during the early and middle periods of 1962, and of check trees

\begin{tabular}{|c|c|c|c|c|c|}
\hline $\begin{array}{l}1962 \text { early } \\
\text { period treatment: } \\
1962 \text { middle } \\
\text { period treatment: }\end{array}$ & Check & Wet & Dry & Wet & Dry \\
\hline \multicolumn{6}{|l|}{ A. Main stem: } \\
\hline Shoot length $(\mathrm{cm})$ & 38.1 & 42.4 & 37.7 & 22.1 & 23.2 \\
\hline Number of fascicles & 329 & 330 & 336 & 325 & 332 \\
\hline $\begin{array}{l}\text { Fascicle density } \\
\text { (No./dm) }\end{array}$ & 86 & 78 & 89 & 147 & 143 \\
\hline Needle length $(\mathrm{cm})$ & 10.0 & 10.0 & 8.0 & 9.3 & 7.8 \\
\hline \multicolumn{6}{|l|}{ B. Third branch whorl: } \\
\hline Shoot length $(\mathrm{cm})$ & 22.7 & 25.1 & 23.2 & 13.1 & 13.8 \\
\hline Number of fascicles & 220 & 222 & 222 & 197 & 203 \\
\hline $\begin{array}{l}\text { Fascicle density } \\
\text { (No./dm) }\end{array}$ & 97 & 88 & 96 & 151 & 147 \\
\hline Needle length $(\mathrm{cm})$ & 9.5 & 9.5 & 7.8 & 8.3 & 7.2 \\
\hline \multicolumn{6}{|l|}{ C. Fifth branch whorl: } \\
\hline Shoot length (cm) & 13.0 & 13.3 & 13.0 & 9.1 & 10.2 \\
\hline Number of fascicles & 166 & 167 & 167 & 159 & 189 \\
\hline $\begin{array}{l}\text { Fascicle density } \\
(\mathrm{No} / \mathrm{dm})\end{array}$ & 128 & 125 & 128 & 175 & \\
\hline Needle length $(\mathrm{cm})$ & 10.0 & 9.8 & 8.0 & 8.1 & \\
\hline
\end{tabular}

\section{Effect of current year only: 1962 foliage development}

All study trees had been subjected to the same environmental preconditioning in 1961, before the study began. The 1962 growth potential in overwintering buds, therefore, was independent of treatments begun that year. Sizes of terminal buds in the fall of 1961 averaged the same for trees in all treatments. In fact the number of needle fascicles produced in 1962 was not significantly different for any treatment (Table 2) at any respective crown position.

In 1962, extension growth of all leaders was greatly influenced by the water supply during the early period, and not by treatments during either the middle or late periods. Long shoots on those trees under drought conditions during April and May grew at a rate $45 \%$ slower on main stems, and averaged $35 \%$ slower on branches, than corresponding shoots on trees receiving water during this period (Fig. 1, Table 2). Evidently the effects of drought and watering during April and May carried over into the middle period. Shoot extension continued until late June in 1962, but regardless of whether trees received water or not during the middle period, their shoots were not significantly different in final length than the pattern of elongation established during the early period.

Since the numbers of dwarf shoot primordia producing foliage in 1962 were equal for all treatments on corresponding shoots, the density of needle fascicles on any terminal shoot was simply inversely

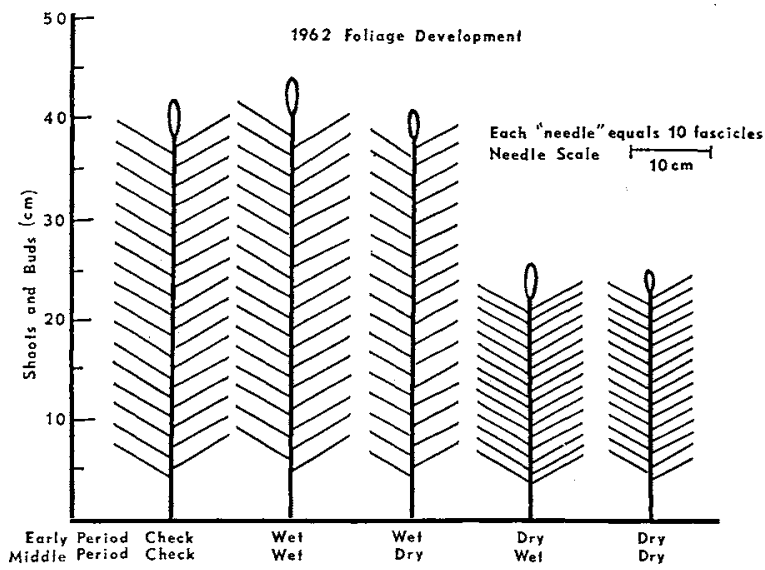

FIG. 1. Diagrams of shoots and needles developed during the 1962 growing season on main stem terminals of trees irrigated or subject to drought during the early and middle periods of that year and of check trees. Each diagram represents the average of all trees in all treatments that provided or withheld water during the periods indicated.

proportional to the extension of the shoot at that crown position (Fig. 1, Table 2). Thus, fascicle density in 1962 was influenced only by the water supply of the early period. On main stem leaders this density averaged $74 \%$ more fascicles per length of shoot for trees under drought during April and May than for trees receiving water during this period.

In 1962 needle elongation at all crown positions was significantly affected by the water supply of only the middle period, June and July, and not by the conditions of either the early or late periods (Fig. 1, Table 2). Needles continued to elongate well into August, but the elongation rate of the middle period set the pattern for the season. Needles were $20 \%$ shorter at corresponding crown positions on trees subjected to drought during June and July than on trees watered during this period. There were no differences measurable, on a week-to-week basis, in dates of initiation of needle elongation that were correlated with water supplies. Needles on all long shoots reached maximum growth rates during the week of July 3 in 1962, regardless of treatment. Likewise the dates of cessation of elongation, in mid-August, were not related to any treatment.

It was thus that four modes of foliage developed from two periods of water treatment in 1962: (1) Needles $9.5 \mathrm{~cm}$ in length occurred with a density of about 145 fascicles per $\mathrm{dm}$ of shoot on trees subjected to drought early in the season and receiving water during midseason; (2) needles $8.0 \mathrm{~cm}$ in length occurred with a density of about 85 fascicles per $\mathrm{dm}$ on trees provided with water early in the season and under drought during mid-season; (3) the longer needles occurred with the lower density when both 
TABLE 3. Needle and shoot production data for terminal shoots developed during 1963. Values are averages for all trees in all treatments providing or withholding water during only the middle period of 1962 and during the entire 1963 season, and of check trees

\begin{tabular}{|c|c|c|c|c|c|}
\hline \multicolumn{6}{|c|}{ 1962-63 water treatments } \\
\hline \multirow{2}{*}{$\begin{array}{l}1962 \text { middle } \\
\text { period treatment: } \\
1963 \text { entire } \\
\text { season trea:ment: }\end{array}$} & Check & Wet & Dry & Wet & Dry \\
\hline & Check & Wet & Wet & Dry & Dry \\
\hline \multicolumn{6}{|l|}{ A. Main stem: } \\
\hline Shoot length $(\mathrm{cm})$ & 39.7 & 42.9 & 33.0 & 30.0 & 19.9 \\
\hline No. fascicles & 350 & 338 & 266 & 350 & \\
\hline $\begin{array}{l}\text { Fascicle density } \\
\text { (No./dm) }\end{array}$ & & & & & \\
\hline & 88 & 79 & 81 & 117 & 126 \\
\hline $\begin{array}{l}\text { Needle length }(\mathrm{cm}) \\
\text { B. Third branch whorl: }\end{array}$ & & & & & 10.5 \\
\hline \multicolumn{6}{|l|}{ B. Third branch whorl: } \\
\hline $\begin{array}{l}\text { Shoot length }(\mathrm{cm}) \\
\text { No. fascicles }\end{array}$ & 16.9 & 17.1 & 11.9 & 10.0 & 8.1 \\
\hline $\begin{array}{l}\text { No. fascicles } \\
\text { Fascicle density }\end{array}$ & 188 & 199 & 145 & & 159 \\
\hline (No./dm) & 111 & 117 & 121 & & 199 \\
\hline Needle length $(\mathrm{cm})$ & 11.3 & 11.3 & 12.8 & 7.5 & 9.3 \\
\hline \multicolumn{6}{|l|}{ C. Fifth branch whorl: } \\
\hline Shoot length $(\mathrm{cm})$ & 10.2 & 9.2 & 7.1 & 5.8 & 5.0 \\
\hline $\begin{array}{l}\text { No. fascicles } \\
\text { Fascicle density }\end{array}$ & 130 & 124 & 108 & 134 & 110 \\
\hline $\begin{array}{l}\text { Fascicle density } \\
\text { (No./dm) }\end{array}$ & 127 & 138 & 152 & 231 & 220 \\
\hline Needle length $(\mathrm{cm})$ & 11.0 & 11.0 & 12.3 & & 8.8 \\
\hline
\end{tabular}

periods were wet; and (4) the shorter needles occurred with the higher density on trees under drought for both periods. The total number of fascicles per shoot was the same for all four of these patterns.

\section{Interaction of two seasons: 1963 foliage development}

Lengths of terminal buds in the fall of 1962 indicated the potential for growth of shoots in the spring of 1963. Those trees subjected to drought during the middle period of the 1962 season had significantly smaller (by at least $30 \%$ ) buds at all crown positions than trees receiving water during this period. The water supply at other periods of the 1962 season had no significant effect on the size of terminal buds.

Extension of terminal shoots in 1963 was significantly affected by the interaction of both seasons' water supplies (Fig. 2, Table 3). The most rapid rate of elongation of leaders at all crown positions was on those trees receiving water both in 1963 and during the middle period in 1962 . The slowest rate of elongation was on those trees subjected to drought both in 1963 and during the middle period in 1962 . The water supply during either the early or late periods in 1962 had no significant influence on 1963 shoot extension, regardless of whether water was supplied or withheld in 1963 or during the middle period in 1962. The difference between the extremes is evident in that the final lengths of main stem leaders on trees wet both seasons were over twice those of leaders on trees dry both seasons (Fig. 2,

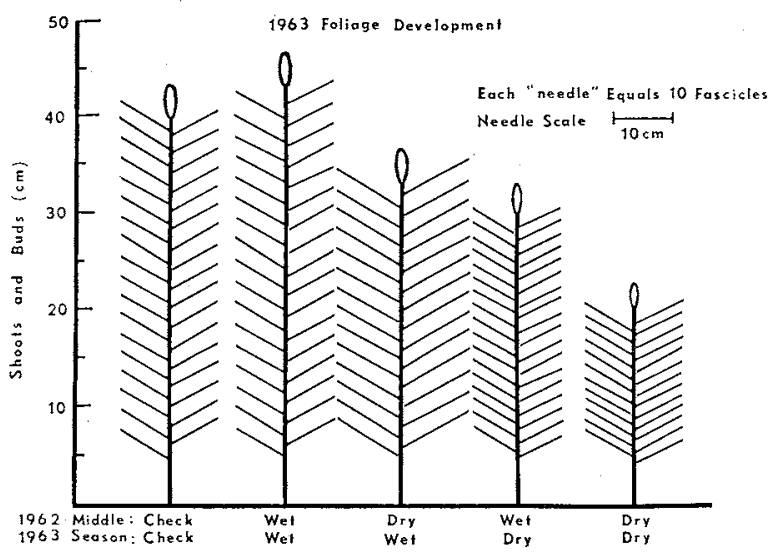

Fig. 2. Diagrams of shoots and needles developed during the 1963 growing season on main stem terminals of trees irrigated or subject to drought during only the middle period of 1962 and during the entire 1963 season, and of check trees. Each diagram represents the average of all trees in all treatments that provided or withheld water during the periods indicated.

Table 3). Halfway between those extremes were shoots on all trees subjected to drought either in 1963 or during the middle period in 1962 . There was no significant difference in lengths of long shoots at any crown position on trees watered in 1963 and dry during mid-season in 1962 on the one hand, and those on trees dry in 1963 and receiving water during mid-season in 1962 on the other.

No measurable differences were noted in dates of initiation of shoot extension in 1963 related to any of the water supply treatments of the previous year. Observations were made only once a week, and there was more variation among individual trees than among treatments. Likewise, there were no measurable differences in cessation of shoot extension in 1963 that were correlated with any water supply treatment of either the previous or the current year. Terminal shoots on trees in all treatments made "measurable extension growth for about 8 weeks in 1963.

The numbers of needle fascicles produced on long shoots in 1963 reflected significantly the water supply of only the middle period (June and July) of the previous season (Fig. 2, Table 3). Trees under drought during this period in 1962 produced $30 \%$ fewer fascicles than trees supplied with water during the same period. Drought early or late in 1962 had no significant effect on reducing the number of dwarf shoot primordia developing into needles, even in combination with drought during the middle period of 1962. The water supply in the second season, 1963, had no significant effect on the number of fascicles produced that year, regardless of whether or not trees had been subjected to drought the previous year. Thus even trees under continuous drought 
in 1962 produced no fewer fascicles when again maintained under drought for the 1963 season than trees under drought just the middle period in 1962 and provided with water for the 1963 season. Likewise trees receiving water continuously in 1962 produced no more fascicles when provided with water again in 1963 than when subjected to drought in 1963.

Density of fascicles on terminal shoots in 1963 was not dependent on the number of fascicles produced, but was dependent on extension growth of the 1963 shoot; thus fascicle density was significantly related to the water supply of only the second season (Fig. 2, Table 3 ). Highest density did not always occur on trees with the greatest overwintering potential for dwarf shoot production, nor on trees with the least amount of shoot elongation. Two treatments, with the same current but different previous year treatments produced high density, about 120 fascicles per $\mathrm{dm}$ of main stem terminal. Likewise two treatments produced relatively low density, averaging 80 fascicles per $\mathrm{dm}$ of main stem shoot. Lower crown positions exhibited higher fascicle densities than did the main stem terminal, but all crown positions were consistent in the effects of treatment. In all cases, the 1963 water supply regulated spacing of fascicles.

Both treatments resulting in the high density of needle fascicles in 1963 were those in which extension of current shoots was restricted by drought in 1963 (Fig. 2, Table 3). One of these treatments had provided water during midseason of the previous year, resulting in large overwintering buds and the production of many fascicles on the current shoot. The other treatment had subjected trees to drought during midseason of the previous year, resulting in small overwintering buds giving rise to a small number of fascicles on the current shoot. Density of fascicles was approximately the same on shoots in both these treatments, because shoot extension was severely restricted in the second case by 2 years of drought and only partially restricted in the first case by 1 year of drought.

The low densities of needle fascicles were on those trees in treatments providing water in the current year (1963) and thus permitting full extension of shoots (Fig. 2, Table 3). One of these treatments had provided water also during the middle of the previous season (1962), resulting in large buds and the production of many needle fascicles. Because rate of current shoot extension was high, these fascicles were spread out at a low density in this treatment. The other treatment with a low density of fascicles in 1963 had subjected trees to drought in June and July of 1962 , resulting in small overwintering buds and few fascicles produced. Shoots on trees in this treatment were intermediate in extension

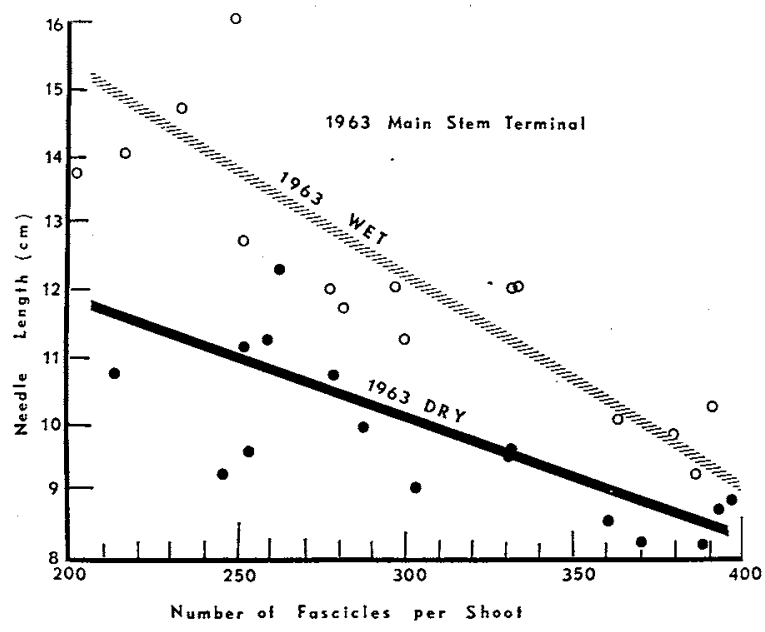

FIG. 3. Relation between needle length and number of needle fascicles produced on a shoot during the 1963 season. Each point is the average of all needles measured on the main stem terminal shoot of a single tree.

growth, spreading out the small number of fascicles to a low density.

Elongation of needles at all crown positions in 1963 was again directly associated with current water supplies, just as it had been in 1962, regardless of previous year's treatments. When water was provided, needles averaged a final length of about $12 \mathrm{~cm}$ at all crown positions in 1963, whereas under current drought conditions, needles grew to an average of 9 $\mathrm{cm}$ on main stems and about $8 \mathrm{~cm}$ on branches (Table 3).

Again in 1963 no observable differences in dates of the beginning and ending of needle elongation were correlated with any treatments. Needles on all trees, regardless of previous or current water supplies, underwent extension growth for approximately the same period of time. There was more variation among individual trees than among treatments, with new needles on the average tree reaching maximum rates of elongation about July 10 , and ceasing growth in mid-August. On all shoots needles at the base of the shoot began extension growth first, and those near the tip of the shoot last. Needles near the tips of shoots on trees receiving water in 1963 expanded equally as long as those near the bases of the same shoots. On trees subjected to drought in 1963, however, needles near the tips of shoots did not reach quite the length of needles at the bases. This difference was small, about $1 \mathrm{~cm}$, but significant.

There was an unexpected significant effect of the previous year's treatments on needle elongation independent of the current water supply. All trees subjected to drought during the middle period in 1962 produced longer needles in 1963 at most stem positions than did trees that had received water 
TABLE 4. Comparison of needle lengths and fascicle numbers on 1963 terminal shoots by treatments differing only during the middle period of 1962 . Averages by crown position for all trees in each treatment

\begin{tabular}{|c|c|c|c|c|c|c|c|c|c|c|}
\hline \multirow{2}{*}{\multicolumn{2}{|c|}{$\begin{array}{c}\text { Treatment } \\
1962 \quad 1963\end{array}$}} & \multicolumn{3}{|c|}{ On main stem } & \multicolumn{3}{|c|}{ On branch whorl 3} & \multicolumn{3}{|c|}{ On branch whorl 5} \\
\hline & & \multirow{2}{*}{$\frac{\begin{array}{c}\text { Length } \\
(\mathrm{cm})\end{array}}{12.2_{* *}}$} & \multirow{2}{*}{$\frac{\text { Number }}{298_{* *}}$} & \multirow{2}{*}{$\begin{array}{c}\begin{array}{c}\text { Length } \\
\text { times } \\
\text { number }\end{array} \\
3,633\end{array}$} & \multirow{2}{*}{$\begin{array}{c}\begin{array}{c}\text { Length } \\
(\mathrm{cm})\end{array} \\
11.7\end{array}$} & \multirow{2}{*}{$\frac{\text { Number }}{172_{\text {水 }}}$} & \multirow{2}{*}{$\begin{array}{c}\begin{array}{c}\text { Length } \\
\text { times } \\
\text { number }\end{array} \\
2,010\end{array}$} & \multirow{2}{*}{$\frac{\begin{array}{c}\text { Length } \\
(\mathrm{cm})\end{array}}{11.4}$} & \multirow{2}{*}{$\frac{\text { Number }}{109}$} & \multirow{2}{*}{$\begin{array}{c}\begin{array}{c}\text { Length } \\
\text { times } \\
\text { number }\end{array} \\
1,246\end{array}$} \\
\hline W D W & W & & & & & & & & & \\
\hline W W W & W & 9.9 & 381 & $3,774^{11 s}$ & $10.4^{\mathrm{ns}}$ & 224 & 2,541 & $10.4^{n}$ & $117^{1}$ & $1,218^{1}$ \\
\hline W D W & D & 9.7 & $253_{* *}$ & $2,442 *$ & 8.4 & $179_{*}$ & 1,500 & 7.4 & 126 & 928 \\
\hline W W W & $\mathbf{D}$ & $8.9^{113}$ & 394 & 3,503 & 7.1 & 212 & $1,508^{\text {us }}$ & $7.4^{11}$ & 184. & $1,355^{\mathrm{n}}$ \\
\hline D D D & W & $15.0_{*}$ & $234_{*}$ & $3,507_{\mathrm{ns}}$ & 14.0 & $118_{*}$ & 1,649 & 14.0 & 107 & 1,440 \\
\hline D W D & W & 12.2 & 295 & 3,597 & 12.2 & 154 & $1,878^{113}$ & $12.0^{1}$ & 90 & 1,074 \\
\hline D D D & D & 11.4 & 251 & 2,869 & 10.4 & 139 & 1,448 & 10.7 & 94 & 1,003 \\
\hline $\mathrm{DWD}$ & D & $9.1^{\circ}$ & 307 & $2,807^{n}$ & $8.1^{*}$ & $129^{n}$ & $1,049^{\text {ns }}$ & 7.1 & $84^{\text {ns }}$ & $597^{\mathrm{ns}}$ \\
\hline \multicolumn{11}{|c|}{$\begin{array}{l}\text { Average of } 1962 \\
\text { Middle period: }\end{array}$} \\
\hline $\mathbf{x} \mathbf{D} x$ & $\mathrm{x}$ & $12.1_{* *}$ & $259_{* *}$ & 3,134 & $11.1_{* *}$ & $152 *$ & 1,687 & 10.9 & 109 & 1,188 \\
\hline $\mathbf{x} W \mathrm{x}$ & $\mathrm{x}$ & 10.0 & 344 & $3,440^{11}$ & 9.4 & 185 & 1,739 & 9.2 & $119^{\circ}$ & 1,095 \\
\hline
\end{tabular}

** $1 \%$ level of significance

* $5 \%$ level of significance

ns no significant difference

during the same period in 1962 (Tables 3 and 4). Shorter needles in 1963 were associated with more fascicles on a shoot (Fig. 3). Thus, regardless of whether current conditions were wet or dry, trees subjected to drought during mid-season of the previous year produced fewer, but longer, needles than did trees with ample water supply the previous year. Because of this interaction, total accumulated needle lengths on a given shoot were more independent of the previous year's conditions than were number of needle fascicles. In fact, whereas analysis showed significantly more fascicles in 1963 on trees receiving water than on trees subjected to drought during the middle period in 1962, a similar analysis of total accumulated needle lengths on a shoot (length of needles times number of needles) showed no significant difference between these two treatments (Table 4). Likewise there was no significant difference in dry weights of all needles on a shoot in 1963 between trees receiving water during the middle of 1962 and those not receiving water in 1962.

In both 1962 and 1963 shoot and needle development on the check trees was equal to or slightly less than that of trees receiving irrigation both years. Rainfall was well below average for the early period of the 1st year, but the drought was not severe enough to alter seriously shoot elongation that year. In early July of both years a natural drought developed over a period of about 2 weeks without rain, a common occurrence in Michigan. These periods of stress were not long enough to reduce significantly needle elongation in either year, or in 1962 the number of primordia developing into needles the subsequent year.

\section{Discussion}

Photosynthetic potential in pines depends largely on the amount and length of leaves and the spacing of needle fascicles along shoots. These three foliage variables are influenced by the environment at different times in shoot ontogeny. The effect of drought, for example, at one stage in ontogeny may be compensated for by other conditions at another stage, so that the net effect is a long-term, year-to-year stability in photosynthetic potential.

It is clear that environmental conditions over at least a 2-year period have strong effects on foliage development in red pine. Midsummer drought the previous year reduces the potential for production of current year needle fascicles, and early season drought the current year reduces extension growth of long shoots. The latter condition especially affects fascicle density. Midseason drought the current year reduces elongation of current needles, while midseason drought the previous year results in somewhat increased elongation of current needles. Thus the interactions of two seasons can be both additive and compensative. A rare combination of circumstances is required to reduce greatly the photosynthetic potential of an annual crop of foliage on red pine by development of shoots with (1) few, (2) closely spaced, and (3) short needles.

It is of special interest that a weather condition common throughout the range of red pine, that of a moderate drought during the middle of a growing 
season, results in two separate effects on foliage development the following year, one compensating for the other in production of photosynthetic surface. When, for example, such a drought reduces the normal complement of primordia from 340 to 270 (a $20 \%$ reduction), elongation of the needles the subsequent year might be $10 \%$ greater than the normal growth, resulting in very little net reduction in photosynthetic potential as a result of the drought. Food and other substances supplied currently from old foliage to newly elongating needles is most likely of a fixed amount regardless of the number of new needle primordia. Thus in the example above each of 270 new needles grows more than each of 340 new needles, so that total elongation and total dry weight of foliage produced are nearly equal in both cases.

The fact that growth of check trees was similar to that of watered trees in this study suggests that natural rainfall in the two seasons, in spite of the moderate natural drought early in the first season, provided adequate moisture for relatively good growth. Early season natural droughts are rare within the range of red pine, and mild midseason droughts are almost annual occurrences. Thus the normal pattern of foliage development on terminal shoots of red pine is intermediate between the three shoots shown on the left in Fig. 2. Trees in this study that received water both years had shoots somewhat longer and needles somewhat shorter than check trees, whereas trees that had water withheld during the middle of the 1st year and received water the 2 nd had shoots somewhat shorter and needles somewhat longer than check trees. Fascicle density was nearly equal for all three types.

Fascicle density was not found to be dependent on some interaction between the 2 years. The spacing of needles on shoots depended on the elongation of internodes between dwarf shoot primordia, and was largely independent of the number of such primordia. Thus fascicle density was influenced only by the moisture treatment of the period when current shoots were elongating, and not by any previous season's treatment (Figs. 1 and 2). Net shoot extension per $s e$ was governed equally by the number of overwintering primordia and by the elongation of internodes between primordia, thus explaining the effect of the environments of two seasons.

Only rarely does fascicle spacing develop on long shoots of red pine so densely that needles are mutually restrictive of light. Early season severe droughts are responsible for this condition. The effect on photosynthesis of high fascicle density has not been measured, but it is generally known that mutual shading by adjacent needles on conifers does reduce photosynthetic potential (Kramer and Kozlowski 1960).

Apparently late season droughts, which are naturally quite common within the range of red pine, have little effect on year-to-year variation in foliage development of this species. Needle numbers, size, and density on trees in this study were all relatively unaffected by withholding water during August and September of the 1st or 2nd year. By contrast, radial growth in red pine has been found significantly affected by late season drought, both in the year of the drought and in the year following (Zahner 1968). The explanation lies in the fact that food relations, especially of current photosynthate, are quite different for terminal and cambial growth in red pine at that time of year (Stone 1969, Schier 1970).

\section{ACKNOWLEDGMENTS}

This research was supported by grant number G-18492 from the National Science Foundation to R. Zahner. The study was conducted while P. W. Garrett was a graduate student at The University of Michigan, and consists of part of his Ph.D. thesis. The authors thank the Huron National Forest, U.S. Forest Service, for use of the pine plantation studied.

\section{Literature Cited}

Clements, J. R. 1970. Shoot responses of young red pine to watering applied over two seasons. Can. J. Bot. 48: 75-80.

Duff, G. H., and N. J. Nolan. 1958. Growth and morphogenesis in the Canadian forest species. III. The time scale of morphogenesis at the stem apex of Pinus resinosa Ait. Can. J. Bot. 36: 687-706.

Kozlowski, T. T. 1963. Growth characteristics of forest trees. J. For. 61: 655-662.

Kramer, P. J., and T. T. Kozlowski. 1960. Physiology of trees. McGraw-Hill Book Co., New York. 642 p.

Lotan, J. E., and R. Zahner. 1963. Shoot and needle responses of 20-year-old red pine to current soil moisture regimes. For. Sci. 9: 497-506.

Marion, G. M., J. V. Berglund, and A. L. Leaf. 1968. Morphological and chemical analyses of red pine (Pinus resinosa Ait.) buds. Plant Soil 28: 313-324.

Sacher, J. A. 1954. Structure and seasonal activity of the shoot apices of Pinus lambertiana and Pinus ponderosa. Am. J. Bot. 41: 749-760.

Schier, G. A. 1970 . Seasonal pathways of ${ }^{14} \mathrm{C}-P$ Photosynthate in red pine labeled in May, July and October. For. Sci. 16: 2-13.

Stone, D. M. 1969. Short term translocation of photoassimilated ${ }^{14} \mathrm{C}$ from different-aged needles of Pinus resinosa saplings. Ph.D. Thesis. Univ. Michigan.

Zahner, $\dot{\mathbf{R}}$. 1968. Water deficits and growth of trees, p. 191-254. In T. T. Kozlowski [ed.], Water deficits and plant growth, vol. 2. Academic Press, New York.

Zahner, R., and A. R. Stage. 1966. A procedure for calculating daily moisture stress and its utility in regressions of tree growth on weather. Ecology 47: 64-74. 